\title{
Seroprevalence of Hepatitis B Surface Antigen and Antibody among Pregnant Women Attending a Tertiary Health Institution in Southwestern Nigeria.
}

\author{
Opaleye Oluyinka Oladele, Salami Saheed, Funmilayo Familua, \\ Olowe Olugbenga Adekunle, Ojurongbe Olusola, Bolaji Oloyede Samuel, \\ Odewale Gbolabo, Ojo Johnson Adeyemi, \\ Department of Medical Microbiology and Parasitology, College of Health Sciences, Ladoke Akintola \\ University of Technology, PMB 4400, Osogbo, Nigeria
}

Keywords: Anti-HBs, HBsAg, pregnant women, vertical transmission

\section{Introduction}

The hepatitis B virus (HBV) induced liver disease is the tenth cause of death worldwide with 500,000 to 1.2 million deaths per year due to chronic hepatitis, liver cirrhosis, and hepatocellular carcinoma [1]. In regions where $\mathrm{HBV}$ incidence is high, there is vertical transmission from an infected mother, either prepartum or perinatally, with the child having greater than $60 \%$ risk of acquiring HBV infection [2]. Particularly, the rate of perinatal infections can be high, reaching up to $90 \%$ [3]. About 10-20\% of women seropositive for hepatitis B surface antigen HBsAg transmit the virus to their neonates in the absence of immunoprophylaxis [4]. Viral hepatitis during pregnancy is associated with high risk of maternal complications such as premature labour, intra-ventricular haemorrhage, intra-partum and post-partum haemorrhage from coagulation failure due to lack of production of vitamin $\mathrm{K}$ dependent clotting factors [5].

There is a high rate of vertical transmission causing fetal and neonatal hepatitis which can have serious effects which may lead to impaired mental and physical health later in life [6] and it is also said to be the most familiar cause of jaundice in pregnancy [7]. Perinatal transmission of this disease occurs if the mother has had acute Hepatitis B infection during late pregnancy, in the first postpartum or if the mother is a chronic hepatitis B surface antigen ( $\mathrm{HBsAg}$ ) carrier [8]. In patients with acute hepatitis B, vertical transmission occurs in up to $10 \%$ of neonates when infection occurs in the first trimester and in $80 \%-90 \%$ of neonates when the infection occurs in the third trimester [9]. Ten to twenty percent of neonates born to HBsAg-positive mothers and $90 \%$ of those born to both HBsAg and HBeAg-positive mothers will be infected with HBV [10, 11]. Immunization with hepatitis B immunoglobulin G (HBIG) and vaccine, administered at birth, reduces the risk of transmission to less than $10 \%$ among infants of mothers who are positive to $\mathrm{HBsAg}$ or $\mathrm{HBeAg}[12,13]$ however this is not yet the practiced in many hospitals in Nigeria.

Studies from different parts of Nigeria have reported varying prevalence rates of HBV among different groups $[14,15,16,17]$. However most studies on pregnant women have dueled on the prevalence of $\mathrm{HBsAg}$, this is the first study in this region to assess the protective immunity to $\mathrm{HBV}$ in pregnant women.

The study evaluated the prevalence of HBsAg and antibody to hepatitis B surface antigen [anti-HBs] in a group of pregnant women in Osogbo, Osun state, Nigeria.

Study area

\section{Materials And Methods}

The study was carried out among pregnant women attending the antenatal clinic of the Ladoke Akintola University of Technology Teaching Hospital in Osogbo, the capital city of Osun state in southwestern Nigeria.

\section{Sample collection and Analysis}

A total number of 183 pregnant women attending the LAUTECH Teaching Hospital antenatal clinic between March and August 2013 were recruited into the study after obtaining their informed consent. Five millilitres of venous blood was collected from individual subjects by venopuncture which was later centrifuged to remove the serum and kept at $-20^{\circ} \mathrm{C}$ until used. $\mathrm{HBsAg}$ was detected using immuno-chromatographic strip (Micropoint Rapid Diagnostic, Italy) sandwiched with monoclonal antibody to HBsAg. The HIV status of the women was determined using HIV Determine HIV1/2 rapid test kit (Heo Bio-Tech, Zhejiang, China).

Anti-HBs was determined using third generation enzyme linked immunosorbent assay (ELISA) (Dia Pro Diagnostic Bioprobes, Italy) method. All tests were carried out following the manufacturers' instruction. Their 
biodata were obtained using structured questionnaire to establish the presence of possible risk factors such as previous history of blood transfusions, number of sexual partners in the past, contact with people infected with hepatitis B virus, tattoos, tribal marks and previous surgical or dental procedures. Ethical approval was obtained from the LAUTECH Teaching Hospital ethical committee for this study.

\section{Data Analysis}

Statistical analysis was computed using STATA 11 package. The results were then subjected to analysis using cross tabulations to explore statistical relationships between variables. Chi square test was used to explore proportional relationship between groups. The level of statistical significance was set at $\mathrm{p}<0.05$ (providing 95\% confidence interval).

\section{Results}

Of 183 blood samples from the pregnant women screened, 13(7.1\%) were positive for HBsAg and 55 $(30.3 \%)$ were positive for anti-HBs (Table 1). The ages of the subjects ranged from 15-49 years (mean age 30.1 years). Majority of the pregnant women screened fall within the age group $25-29$ years. The highest prevalence rate for $\mathrm{HBsAg}$ of $46.2 \%$ and anti-HBs of $34.5 \%$ were observed in the age group 25 - 29years (Table 1).

A good number of the women 141/183 (77\%) tested had at least tertiary education, while $42(23 \%)$ were below tertiary education level (Table 1). Of the 183 subjects, 14 had multiple sexual partners of which 1(7.1\%) was positive for HBsAg while 4/14 (28.6\%) were positive for anti-HBs. Twenty eight women had previous history of surgery / dental procedure however only 1/28 (3.6\%) was positive for HBsAg and 6/28 $(21.4 \%)$ were positive for anti-HBs.

Of the 27 with tribal marks none of them was positive for HBsAg while 9/27 (33.3\%) were positive for anti-HBs, $8(53.3 \%)$ of the 15 pregnant women with the history of hepatitis B vaccination were positive for Anti-HBs while none was positive for HBsAg (Table 2).

Fifty six of the women screened had an history of contact with a relative, a spouse, a friend or someone with hepatitis B infection in the past, among these, 16/56 (28\%) were positive for HBsAg while 9/56 (16.1\%) were positive for anti-HBs.

When considering the women's occupation as a risk factor of acquisition of HBsAg, there were 20 healthcare workers and 163 non healthcare workers sampled. Of the 20 healthcare workers $9(45 \%)$ tested positive to HBsAg and 6(30\%) was positive to Anti-HBs

Five $(5.4 \%)$ of the 92 pregnant women screened for HIV were found positive, 1 (20\%) of these had HBV/HIV co-infection, making the co-infection rate among the group screened to be $1.1 \%$

Table 1: Socio-demographic characteristics of the pregnant women

\begin{tabular}{|l|c|l|l|l|}
\hline Characteristic & Number (n) & Percent (\%) & $\begin{array}{l}\text { HBsAg (+) } \\
\text { N =13 }\end{array}$ & $\begin{array}{l}\text { Anti-HBs (+) } \\
\text { N = 55 }\end{array}$ \\
\hline $\mathbf{1 5 - 1 9}$ & 4 & 2.2 & $0(0 \%)$ & $2(50 \%)$ \\
$\mathbf{2 0 - 2 4}$ & 18 & 9.8 & $1(5.6 \%)$ & $6(33.3 \%)$ \\
$\mathbf{2 5 - 2 9}$ & 71 & 38.8 & $6(8.5 \%)$ & $19(27 \%)$ \\
$\mathbf{3 0 - 3 4}$ & 49 & 26.8 & $1(2.0 \%)$ & $15(30.6 \%)$ \\
$\mathbf{3 5 - 3 9}$ & 33 & 18 & $4(12.1 \%)$ & $9(27.3 \%)$ \\
$\mathbf{4 0 - 4 4}$ & 7 & 3.8 & $1(14.3 \%)$ & $4(57.1 \%)$ \\
$\mathbf{4 5 - 4 9}$ & 1 & 0.6 & $0(0 \%)$ & $0(0.0 \%)$ \\
\hline Educational level & & & & \\
\hline Primary & 2 & 1.1 & $1(2.5 \%)$ & $2(100 \%)$ \\
Secondary & 40 & 21.9 & $12(8.5 \%)$ & $11(27.5 \%)$ \\
Tertiary & 141 & 77 & & $42(30 \%)$ \\
\hline Religion & & $3(5.0 \%)$ & \\
\hline Islam & 61 & 33.3 & $10(8.2 \%)$ & $13(21.3 \%)$ \\
Christianity & 122 & 66.7 & & $42(34.4 \%)$ \\
\hline Ethnicity & & $13(100 \%)$ & \\
\hline Yoruba & 174 & 95.1 & $0(0 \%)$ & $52(30 \%)$ \\
Igbo & 5 & 2.7 & $0(0 \%)$ & $2(40 \%)$ \\
Hausa & 4 & 2.2 & & $1(25 \%)$ \\
\hline
\end{tabular}


Seroprevalence Of Hepatitis B Surface Antigen And Antibody Among Pregnant Women Attending A

Table 2: Predisposing factors to hepatitis B virus and the HBsAg, Anti-HBs status in the pregnant women screened

\begin{tabular}{|c|c|c|c|c|c|c|c|}
\hline Variables & Number & $\begin{array}{l}\text { HBsAg } \\
(+)\end{array}$ & $\mathbf{X}^{2}$ & P-value & $\begin{array}{l}\text { Anti- } \\
\text { HBs(+) }\end{array}$ & $\mathbf{X}^{2}$ & P-value \\
\hline $\begin{array}{l}\text { Multiple sexual partners } \\
\text {-Yes } \\
\text {-No }\end{array}$ & $\begin{array}{l}14 \\
169\end{array}$ & $\begin{array}{l}1(7.1 \%) \\
12(7.1 \%)\end{array}$ & 0.000 & 0.995 & $\begin{array}{l}4(28.8 \%) \\
51(30.2 \%)\end{array}$ & 0.016 & 0.900 \\
\hline $\begin{array}{l}\text { Previous history of Surgery/Dental procedure } \\
\text {-Yes } \\
\text {-No }\end{array}$ & $\begin{array}{l}28 \\
155\end{array}$ & $\begin{array}{l}1(3.6 \%) \\
12(7.7 \%)\end{array}$ & 0.625 & 0.429 & $\begin{array}{l}6(21.4 \%) \\
49(31.6 \%)\end{array}$ & 1.170 & 0.279 \\
\hline $\begin{array}{l}\text { Previous history of Blood transfusion } \\
\text {-Yes } \\
\text {-No }\end{array}$ & $\begin{array}{l}12 \\
171\end{array}$ & $\begin{array}{l}0(0.0 \%) \\
13(7.6 \%)\end{array}$ & 0.982 & 0.322 & $\begin{array}{l}6(50 \%) \\
49(28.7 \%)\end{array}$ & 2.430 & 0.119 \\
\hline $\begin{array}{l}\text { History of Circumcision } \\
\text {-Yes } \\
\text {-No }\end{array}$ & $\begin{array}{l}39 \\
144\end{array}$ & $\begin{array}{l}3(7.7 \%) \\
10(7.0 \%)\end{array}$ & 0.026 & 0.872 & $\begin{array}{l}12(30.8 \%) \\
43(29.9 \%)\end{array}$ & 0.012 & 0.913 \\
\hline $\begin{array}{l}\text { History of tribal marks } \\
\text {-Yes } \\
\text {-No }\end{array}$ & $\begin{array}{l}27 \\
156\end{array}$ & $\begin{array}{l}0(0.0 \%) \\
13(8.3 \%)\end{array}$ & 2.422 & 0.120 & $\begin{array}{l}9(33.3 \%) \\
46(29.9 \%)\end{array}$ & 0.162 & 0.687 \\
\hline $\begin{array}{l}\text { History of tattoos } \\
\text {-Yes } \\
\text {-No }\end{array}$ & $\begin{array}{l}5 \\
178\end{array}$ & $\begin{array}{l}1(20.0 \%) \\
12(6.7 \%)\end{array}$ & 1.295 & 0.255 & $\begin{array}{l}3(60 \%) \\
52(29.2 \%)\end{array}$ & 2.193 & 0.139 \\
\hline $\begin{array}{l}\text { History of hepatitis B vaccination } \\
\text {-Yes } \\
\text {-No }\end{array}$ & $\begin{array}{l}15 \\
168\end{array}$ & $\begin{array}{l}0(0.0 \%) \\
13(7.7 \%)\end{array}$ & 1.249 & 0.264 & $\begin{array}{l}8(53.3 \%) \\
47(28 \%)\end{array}$ & 4.212 & 0.040 \\
\hline $\begin{array}{l}\text { Occupation } \\
\text { - Health worker } \\
\text {-Non Health worker }\end{array}$ & $\begin{array}{l}20 \\
163\end{array}$ & $\begin{array}{l}6(30 \%) \\
7(4.2 \%)\end{array}$ & 17.837 & 0.000 & $\begin{array}{l}9(45.0 \%) \\
46(27.4 \%)\end{array}$ & 2.386 & 0.122 \\
\hline $\begin{array}{l}\text { History of previous contact with } \mathrm{HBV} \text { infected } \\
\text { person } \\
\text {-Yes } \\
\text {-No }\end{array}$ & $\begin{array}{l}56 \\
127\end{array}$ & $\begin{array}{l}9(16.1 \%) \\
4(3.1 \%)\end{array}$ & 9.833 & 0.002 & $\begin{array}{l}16(28 \%) \\
39(31 \%)\end{array}$ & 0.084 & 0.771 \\
\hline
\end{tabular}

$\mathbf{N}=183$

\section{Discussion}

Screening asymptomatic people is an important instrument in disease detection, prompt diagnosis and intervention particularly at an early stage of disease. From this study the prevalence HBsAg of $7.1 \%$ observed among pregnant women in Osogbo Osun state Nigeria is consistent with the prevalent rate 7.3\% reported among pregnant women in Kano also in Nigeria [18]. The prevalence of HBsAg from this study is lower than 7.6\% prevalent rate reported in Nnewi [19], 9.3\% in Awka [20], 11\% in Makurdi [21], 15.8\% in Maiduguri [22], and $63.3 \%$ in Jos [23] all among pregnant women in Nigeria. However, the prevalence reported in this study is higher than the prevalence of 2.2\% from a study in Benin-city, [24], 4.3\% in Port-Harcourt [25], 5.7\% in Ilorin [26]. 4.4\% in Lagos [27] and 4.6\% in Enugu [28], all in Nigeria. These findings show that HBV is endemic in Nigeria and that it is very important to screen pregnant women for the virus and appropriate steps should be taking to prevent vertical transmission.

Although screening of pregnant women for HBsAg is perfectly in order, however, without a protective immunity against the HBV infection these women can still stands the risk of contacting the infection. In this study only $30 \%$ of the pregnant women screened had protective antibody against HBV perhaps by virtue of previous exposure to the virus or as a result of seroconversion following vaccination. It is however surprising that only $8 / 15(53.3 \%)$ of the people that claimed to have received HBV vaccination were positive for anti-Hbs these might be due to the fact that a complete dose of the vaccine was not received or due to the fact that they are HBV carriers even before receiving the vaccine.

In this study, HBsAg was highest among the age group 25-29years. The findings from this study was in agreement with the findings from the study by Habiba et al, where majority of those that tested positive to HBsAg were in the age range of 25-35 years [29]. This correlates with the peak age of highest sexual activity in the society, hence supporting the role of sexual intercourse in the transmission of hepatitis B virus [18]. The result also agrees with the report of Aganga et al [30] that in populations in which hepatitis B virus is relatively common, the majority of infections and peak prevalence of HBsAg as well as specific antibody were in the age group 25-29 and 30-34 years. A similar finding was noted in the study by Vazquez-Martinez et al who observed that the average age of women infected with the Hepatitis B virus in Mexico was 26 years [31].

Another important factor in this study was the level of education. The prevalence of HBV was directly associated with increased educational status. Thus, the more educated the pregnant women, the higher the prevalence rates faulting the influence of education and public enlightenment/awareness on the carrier rates of this infection. This is contrary to what was reported by Ezegbudo et al. [20]. 
It was noted from this study that previous contact with somebody with hepatitis infection was statistically significant predisposing factor to HBsAg infection $\left(\chi^{2}=9.833, p=0.002\right)$ The risk of transmission of HBV has been known to be high in people who are in contact with chronically infected subjects [32]. The presence of body inscriptions like scarification marks or tattoos, multiple sexual partners, previous history of sexually transmitted infections, previous histories of blood transfusion and previous surgeries/dental manipulations were not statistically significantly associated with HBV infection from this study. This is in keeping with the study in Port-Harcourt, Nigeria [24].

From this study, 6 [30\%] of the 20 health care workers screened were positive for HBsAg. This was statistically significant $\left(\chi^{2}=17.837, p<0.05\right)$ corroborating the study in Nnewi, Nigeria [33]. It is expected that pregnant health care workers are supposed to know about the modes of transmission of HBsAg and thus protect themselves from getting infected. However, those in high risk health departments like blood transfusion services or theatres may be more predisposed to acquiring the infection compared to health care workers in pharmacies, out-patient departments and administrative departments of hospitals.

The HBV/HIV co-infection rate in this study was not statistically significant however the rate was higher than the $0.7 \%$ co-infection rate among pregnant women screened in Awka, Nigeria, [20] but less than that reported in Jos also in Nigeria [34]. The finding of this study is similar to that of Ahmed et al which showed that there was no statistical evidence to suggest that HIV positivity was associated with increase prevalence of HBV [35].

Without prophylaxis, the risk of mother-to-child transmission of $\mathrm{HBV}$ is very high. It varies with the $\mathrm{HBeAg} / \mathrm{anti}-\mathrm{HBe}$ status of mothers, being $70 \%-90 \%$ for $\mathrm{HBeAg}$-positive mothers, $25 \%$ for $\mathrm{HBeAg}$ negative/HBeAb-negative mothers and $12 \%$ for $\mathrm{HBeAg}$-negative/anti-HBe-positive mothers [36].

In conclusion, our study has been able to show the possibility of vertical transmission of HBV among the pregnant women that tested positive for HBsAg. Infected new born most often remains a chronic carrier with the attendant consequences of liver cirrhosis and hepatocellular carcinoma later in life. We therefore recommend that HBsAg carrier pregnant mothers be identified and a passive-active immunoprophylaxis be administered to their babies at birth to reduce the risk of vertical transmission according to previous studies [37, 38]. Moreover we equally advocate that anti-HBs screening should be done for all antenatal patients and those negative should be vaccinated to help them develop protective immunity to HBV infection.

\section{References}

[1]. Mahoney FJ (1999) Update on diagnosis, management, and prevention of hepatitis B virus infection. Clinical Microbiology Reviews 12:351-366.

[2]. Alter, M (1996) Epidemiology and disease burden of hepatitis B and C. Antiviral Therapy 1:9-15.

[3]. Gust ID (1996) Epidemiology of hepatitis B infection in the Western Pacific and South East Asia.Gut 38 :S18-23.

[4]. Center for Disease Control and Prevention (CDC), (2008) Hepatitis B Virus (HBV). In: Infections During Pregnancy.

[5]. Gambarin-Gelwan, M (2007). Hepatitis B in Pregnancy. Clinics of Liver Disease. 11(4):945 963.

[6]. Elinav, E; Ben-Dov, IZ; Shapira, Y; Daudi, N; Adler, R; Shouval, D; Ackerman, Z (2006) Acute hepatitis A infection in pregnancy is associated with high rates of gestational complications and preterm labor. Gastroenterology 130: 1129-1134.

[7]. Hill, JB; Sheffield, JS; Kim, MJ; Alexander, JM.; Sercely, B;Wendel, GD (2002) Risk of hepatitis B transmission in breast-fed infants of chronic hepatitis B carriers. Obstetrics \& Gynaecology 99:1049-52.

[8]. Levy, M and Koren, G (1991) Hepatitis B vaccine in pregnancy: Maternal and fetal safety. American Perinatal Journal 8:227-232.

[9]. ACOG educational bulletin. Viral hepatitis in pregnancy (1998) American College of Int J Gynaecol Obstet 8;63(2):195-202.

[10]. Chang MH. Chronic hepatitis virus infection in children (1998) J Gastroenterol Hepatol.

[11]. 13(5):541-8.

[12]. Stevens CE, Beasley RP, Tsui J, Lee WC. (1975) Vertical transmission of hepatitis B antigen in Taiwan. N Engl J Med. 292(15):771-4.

[13]. Andre FE, Zuckerman AJ (1994) Review: protective efficacy of hepatitis B vaccines in neonates. J Med Virol. 44(2):144-51.

[14]. Tosun SY, Yücetürk M, Benzergil S. (2002) HBsAg Pozitif Gebelerden Dogan Bebeklerin ImmuNizasyonu. Ege J Med 41(1):21-3.

[15]. Imoru M, Eke C, Adegoke A. (2003). Prevalence of Hepatitis-B Surface Antigen (HbsAg), Hepatitis C Virus (HCV) and Human Immunodeficiency Virus (HIV) among Blood Donors in Kano State, Nigeria. Journal of Medical Laboratory Sciences 12(1):59-63.

[16]. Ejele OA, Ojule AC (2004) The Prevalence of Hepatitis B Surface Antigen (HBsAg) among prospective blood donors and patients in Port Harcourt, Nigeria. Nigerian Journal of Medicine; 13:336-338 (s)

[17]. Alao O, Okwori E, Egwu C, Audu F. (2009) Seroprevalence of Hepatitis B Surface Antigen Among Prospective Blood Donors In An Urban Area Of Benue State. The Internet Journal of Hematology; 5(2)

[18]. Opaleye O.O, Zakariyahu T.O., Tijani B.A., Bakarey A.S (2010) HBV and HCV Infections in Blood Donors in Southwest Nigeria. Indian Journal of Pathology and Microbiology 53 (1): 182-183.

[19]. Dawaki SS, Kawo AH (2006). Seroprevalence of Hepatitis B surface antigen (HBsAg) in pregnant women attending an urban maternity hospital in Kano, Nigeria. Nig. J. Microbiol. 20: 705-709.

[20]. Chukwuka JO, Ezechukwu CC, Egbunonu I and Okoli CC (2004) Prevalence of hepatitis B surface antigen in primary school children in Nnewi, Nigeria. Nigerian Journal of Clinical Practices 7(1): 8-10.

[21]. Ezegbudo CN, Agbonlahor DE, Nwobu GO, Igwe CU, Agba MI, Okpala HO (2004) The Sero-prevalence of Hepatitis B surface antigen and Human Immuno deficiency Virus (HIV) among pregnant women in Anambra State. Shiraz E-Medical Journal 5(2):18 .

[22]. Mbaawuaga EM, Enenebeaku MNO, Okopi JA, Damen JG (2008) Hepatitis B virus Infection (HBV) among pregnant women in Makurdi, Nigeria. African Journal of Biomedical Research 11:155-159.

[23]. Baba MM, Onwuka IS, Baba SS (1999) Hepatitis B and C infections among Pregnant women in Maiduguri, Nigeria. Central European Journal of Public Health 7(2):60-62. 
[24]. Imade GE, Sagay AS, Ugwu BT, Thacher TD, Ford RW (2004) Seroprevalence of hepatitis B and HIV infections in pregnant women in Nigeria. J Med. Trop 6: 15: 21 .

[25]. Onakewhor JU, Okonofua FE, Offor E(2001) Maternal and neonatal seroprevalence of Hepatitis B surface antigen (HBsAg) in Benin City, Nigeria. Journal of Obstetrics and Gynaecology 21(6):583-586.

[26]. Akani CI, Ojule AC, Opurum HC, Ejilemele AA (2005) Sero-prevalence of Hepatitis B surface antigen (HBsAg) in pregnant women in Port-Harcourt, Nigeria. Nigeria Post-graduate Medical Journal 12(4):266-270

[27]. Agbede OO, Iseniyi JO, Kolawole OM, Ojuawo A(2007) Risk factors and Seroprevalence of hepatits B surface antigenemia in mothers and their pre-school age children in Ilorin, Nigeria. Future Med Therapy 4(1):67-72.

[28]. Obi CL, Nnatu SN, Anyiwo CE, Agbonlahor DE, Esumeh FI, Karpas A (1993) A comparison of HIV seropositivity and Hepatitis B surface antigenemia (HBsAg) among the same group of apparently healthy pregnant women in Lagos, Nigeria: a preliminary report. Viral Immunology 6(1):43-47.

[29]. Obi SN, Onah HE, Ezugwu FO (2006) Risk factors for Hepatitis B infection during pregnancy in a Nigerian population. International Journal of Obstetrics and Gynecology 26(8):770-772.

[30]. Habiba SA, Memon, MA (2007). Prevalence of Hepatitis B infection in pregnant women in a tertiary care hospital. Infectious Disease Journal of Pakistan 35-38.

[31]. Aganga WOM, Akanmu AS, Akinsete A, Njoku OS (1999) Prevalence of hepatitis B surface antigen among women of childbearing age. Afr J Rep 3(1):45-50.

[32]. Vazquez-Martinez, J, Coreno-Juarez, MO, Montano-Estrada, LF, Michael, A. and Gomez-Dantez, H (2003) Sero-prevalence of Hepatitis B in pregnant women in Mexico. Salud Pública De México 45(3):165-170.

[33]. Ion-Nedelcu, N., Mihaileanu, C., Dobrescu, A (1989) The risks of transmitting viral hepatitis in a section of the city of Bucharest. Rev Ig Bacteriol Virusol Parazitol Epidemiol Pneumoftiziol Bacteriol Virusol Parazitol Epidemiol 34(2):155-162.

[34]. Eke AC, Uzoamaka A, Charles I, Ifeanyichukwu U. (2011) Prevalence, correlates and pattern of hepatitis B surface antigen in a low resource setting. Virology Journal 8:12

[35]. Uneke CJ,Ogbu O,Inyama PU,Anyanwu GI,Njoku MO,Idoko JH (2005) Prevalence of Hepatitis B surface antigen among blood donors and Immunodeficiency virus-infected patients in Jos,Nigeria,Mem Inst Oswaldo Cruz 100:13-6

[36]. Ahmed SD,Cuevas LE,Brabin BJ,Kazembe P,Broadhead R,Verhoeff AH,Hart C (1998) Seroprevalence of hepatitis B and C and HIV in Malawian pregnant women.Journal of infectious diseases 37(3):248-251

[37]. Bai, H., Zhang, L., Ma, L., Dou, X. G, Feng, G. H., Zhao, G. Z (2007) Relationship of hepatitis B virus infection of placental barrier and hepatitis B virus intra-uterine transmission mechanism. World J Gastroenterol 13: 3625-3630.

[38]. Van Herck, Koen MD, Van Damme, Pierre (2008) Benefits of Early Hepatitis B Immunization Programs for Newborns and Infants Pediatric Infectious Disease Journal 27(10): 861-869

[39]. Tran, T. T. (2009). Management of hepatitis B in pregnancy: weighing the options. Cleve Clin J Med 3: 25-29. 